\title{
Research to guide management of outdoor recreation and tourism in parks and protected areas
}

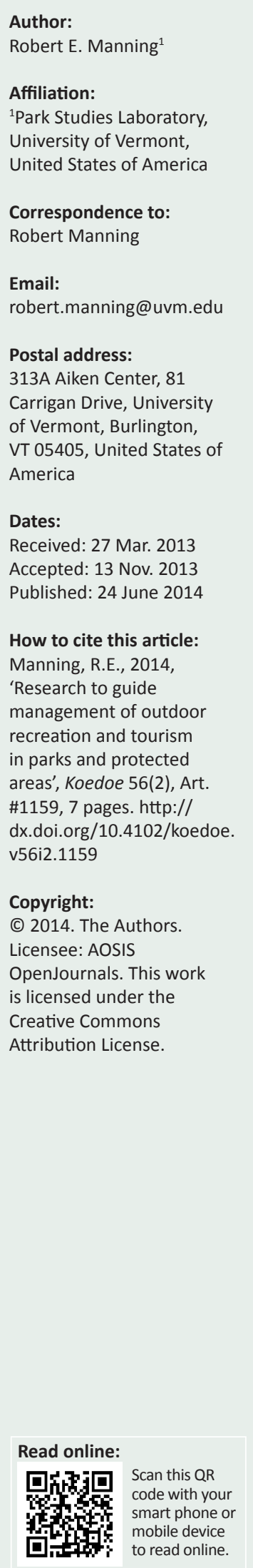

A framework for managing outdoor recreation and tourism in parks and protected areas was presented in this article. This management-by-objectives framework includes, (1) formulating indicators and standards of quality, (2) monitoring indicators of quality and (3) implementing management actions designed to maintain standards of quality. This management framework can be used to help balance the demand for outdoor recreation and tourism and the need to protect park resources and the quality of the visitor experience. A programme of research to help guide application of this management framework was described and illustrated. This research is part of a growing body of scientific and professional literature on outdoor recreation and tourism that can be used to build the capacity of park and protected area management agencies.

Conservation implications: The management framework described in this article, and the associated programme of research, can be used by conservation practitioners to balance use and protection of national parks and protected areas.

\section{Introduction}

Parks and protected areas are becoming increasingly important in contemporary society. Parks are vital to people in many ways: they offer open, green spaces in our ever-developing world, they are retreats from the hectic lives that many of us lead and they protect wildlife and other elements of biodiversity, as well as historical and cultural resources that are important markers of society. And, of course, tourism and outdoor recreation are also important, offering healthy and satisfying leisure activity, intimate contact with the out-of-doors, opportunities to build family solidarity, enjoyment and appreciation of our natural environment and cultural heritage, employment and economic development to local people and communities and a myriad of other benefits.

Because of their importance, parks and protected areas have been established across the globe. Formally designated national and international protected areas now number over 150 000, include more than 24 million $\mathrm{km}^{2}$ of land and water and cover more than $12 \%$ of the surface of the earth (International Union for Conservation of Nature \& United Nations Environment Programme World Conservation Monitoring Centre 2011, 2012). Tourism and outdoor recreation have also grown exponentially (Balmford et al. 2009). Worldwide tourism has been estimated to account for $10 \%$ of gross domestic product and outdoor recreation and wildlife viewing make up one of tourism's fastest growing sectors (Davenport et al. 2002; Goodwin 1996; Mastny 2001; World Travel and Tourism Council 2007).

But how can parks and protected areas be managed to maximise their effectiveness? In particular, parks and protected areas are generally established to meet two objectives, (1) protect park resources and the quality of the visitor experience and (2) accommodate visitor use and enjoyment. These objectives can be complementary when visitor use leads to widespread support for parks and protected areas, including economic development opportunities for local communities and needed revenues to manage parks. However, these objectives can often come into conflict when the amount and type of visitor use leads to unacceptable impacts on park resources and the quality of the visitor experience. This paper addresses a programme of research and management designed to help maximise attainment of management objectives and minimise potential conflict between these objectives.

\section{A management framework}

A number of frameworks have been developed to help guide management of outdoor recreation and tourism in parks and protected areas. Prominent examples include limits of acceptable change (LAC) developed by the US Forest Service (McCool 1994; McCool \& Cole 1997; Stankey et al. 1985) and visitor experience and resource protection (VERP) developed by the US National Park 
Service (Manning 2001, 2007, 2009; National Park Service 1997). Whilst there are some differences in terminology and sequencing of steps, these and related management-byobjectives frameworks rely on the three basic steps as shown in Figure 1 and described below (Manning 2004).

Firstly, management objectives and associated indicators and standards of quality are formulated for a park or site within a park. Management objectives describe desired conditions - the level of resource protection and the type and quality of recreation experiences - to be maintained. Associated indicators and standards of quality define these objectives in quantitative, measurable form. Secondly, indicators of quality are monitored to determine if standards of quality are being maintained. Thirdly, if standards of quality are violated, or are in danger of being violated, then management action is required.

This management framework represents a long-term commitment to management that requires maintaining standards of quality, periodic monitoring of indicators of quality and reconsideration of management practices based on monitoring data. When circumstances warrant, for example when a management plan has reached the end of its useful life and needs to be revised, management objectives and associated indicators and standards of quality can be reconsidered.

The management framework outlined above is built on foundational concepts that have emerged in the environmental literature. For example, it represents a form of 'adaptive management'; that is, it is implemented based on the best information available, but new information is gathered in an ongoing programme of monitoring and research and management practices are revised in keeping with this new information (Christensen et al. 1996; Holling 1978; Lee 1993; Stankey, Clark \& Bormann 2005; Walters 1986). It uses management objectives and associated indicators and standards of quality as quantitative expressions of the 'carrying capacity' of parks and protected areas: the type and amount of use that can be accommodated without unacceptable impacts to park resources and the quality of the visitor experience (Graefe, Vaske \& Kuss 1984; Manning 2007, 2011a; Shelby \& Heberlein 1986; Stankey \& Manning 1986; Wagar 1964; Whittaker et al. 2011). The framework requires that management actions be implemented when monitoring shows that standards of quality are in danger of being violated and this is keeping with the call for deliberative management as demanded in the context of common property resources (of which parks and protected areas are classic examples) (Hardin 1968). Management objectives and associated indicators and standards of quality can and should be derived from ecological research and knowledge, along with public participation and engagement as suggested by the concept of 'ecosystem management' (Agee \& Johnson 1987; Grumbine 1994; Society of American Foresters 1993).

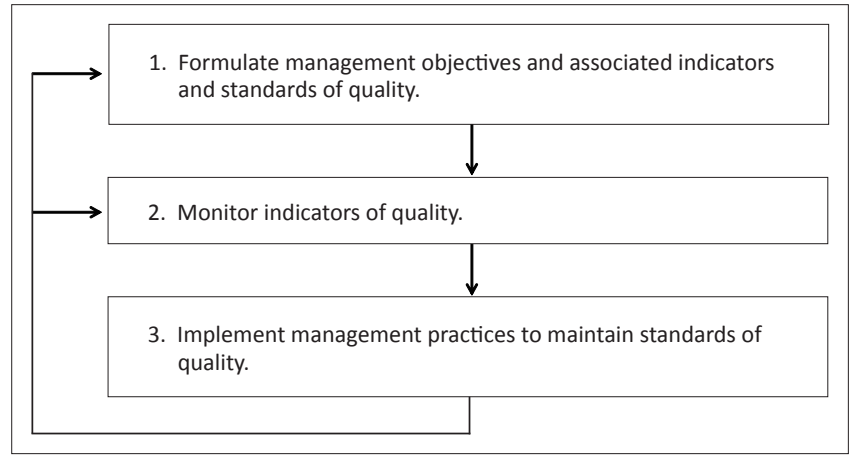

Source: Author's own creation

FIGURE 1: A framework for managing outdoor recreation and tourism in parks and protected areas.

\section{Research to support management}

Application of the management framework described above can and should be supported by a programme of research. This section of the article outlines examples of a series of studies conducted in national parks to help inform each of three basic steps of the management framework described in the previous section. This programme of research, (1) uses surveys of park visitors and other stakeholders and visual simulations of a range of park and outdoor recreation conditions to help guide formulation of indicators and standards of quality, (2) develops a computer simulation model of recreation use to monitor crowding-related standards of quality and (3) tests the efficacy of management practices designed to maintain standards of quality.

\section{Formulating indicators and standards of quality}

A programme of research was designed to help support formulation of indicators and standards of quality at Arches National Park (Manning \& Freimund 2004; Manning et al. 1996). Arches covers 29500 ha of high-elevation desert in south-east Utah and is named after the nearly 2000 distinctive natural sandstone arches in this area. A road connects many of the most iconic features of the park and this contributes to rapidly growing visitation that now numbers more than a million visits per year. The programme of research was conducted in two phases.

Phase I explored potential indicators of quality for the visitor experience. Interviews were conducted with Park visitors and 10 focus group sessions were held with Park staff, local community residents and representatives of key stakeholder groups. Interviews and focus groups asked participants what they considered to be the most important factors that defined the quality of the visitor experience at Arches. Study findings suggested that the most important indicators were, (1) number of visitors seen at attraction sites and along trails, (2) the presence of social trails (visitor-made informal trails) and associated soil and vegetation impacts and (3) visitor knowledge of Park regulations about hiking off official, maintained trails.

Phase II research was designed to help formulate standards of quality for the indicator variables noted above. A survey of 

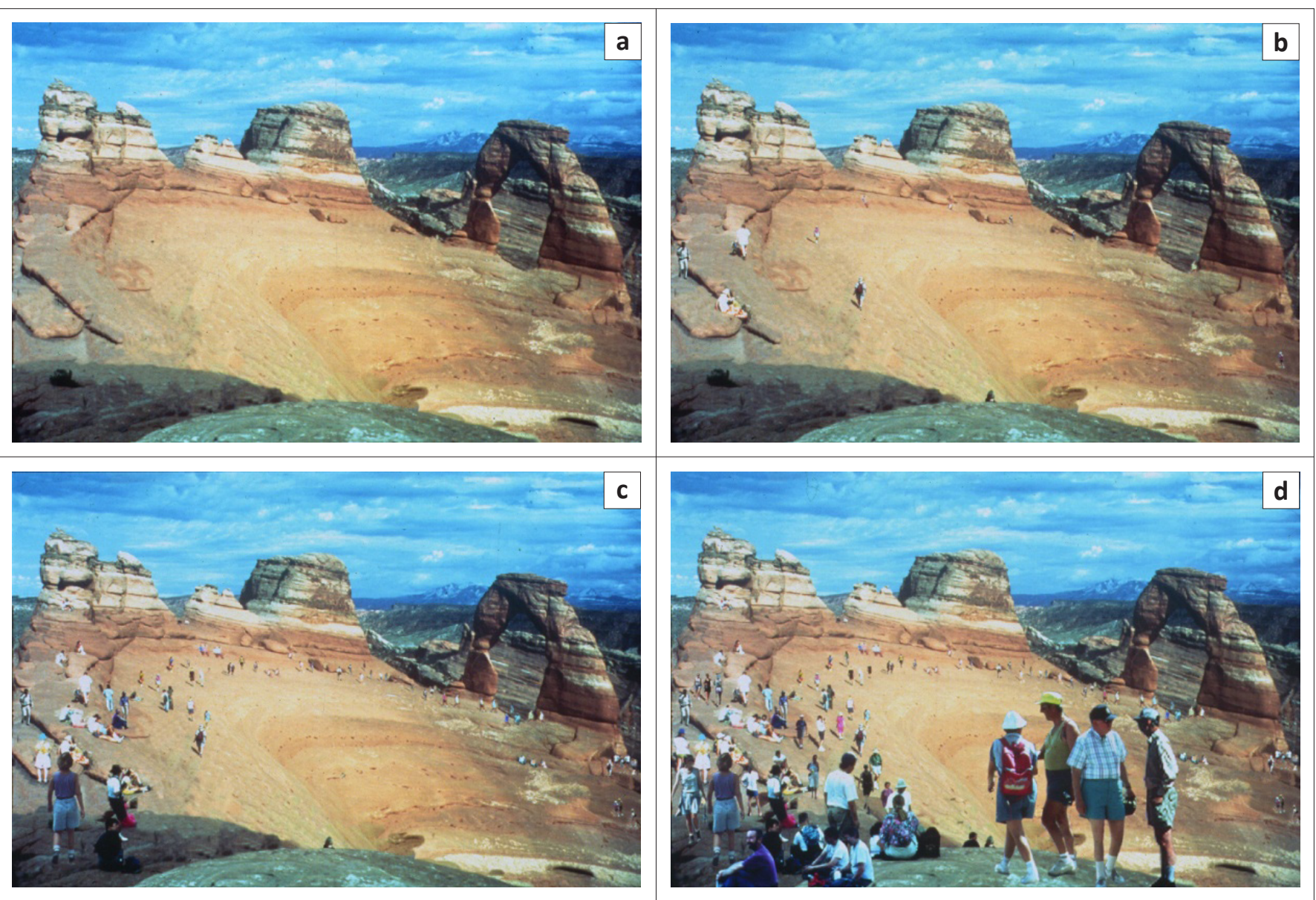

Source: Photographs prepared by Wayne Freimund, University of Montana, Robert Manning, University of Vermont and David Lime, University of Minnesota

FIGURE 2: Sample computer-generated photographs illustrating a range of use levels in terms of people at one time at Delicate Arch in Arches National Park, Utah, with (a) 0 people, (b) 12 people, (c) 52 people and (d) 108 people.

Park visitors was conducted using both personal interviews and mail-back questionnaires. Visual research methods were used to illustrate a range of conditions for indicator variables. For example, a series of 16 computer-generated images was created to represent a range of visitor use levels at Delicate Arch, a principal visitor attraction. These images were created using photo-editing software and examples of these images are shown in Figure 2. These images were presented to a representative sample of visitors who had just completed a hike to Delicate Arch. Respondents were asked to judge the acceptability of each image on a scale of -4 ('very unacceptable') to +4 ('very acceptable'). Analogous sets of images were created for the number of hikers along developed trails and environmental impacts caused by offtrail hiking.

Study findings for the acceptable number of people at Delicate Arch are shown in Figure 3. This figure represents the average (mean) acceptability ratings for each of the 16 study images. It is clear from the graph that acceptability declines with increasing use. Average acceptability ratings fall out of the acceptable range and into the unacceptable range at about 30 people at one time (PAOT) at Delicate Arch and Park staff selected this number as the minimum acceptable standard of quality. In a similar manner, standards of quality were formulated for other indicator variables and other

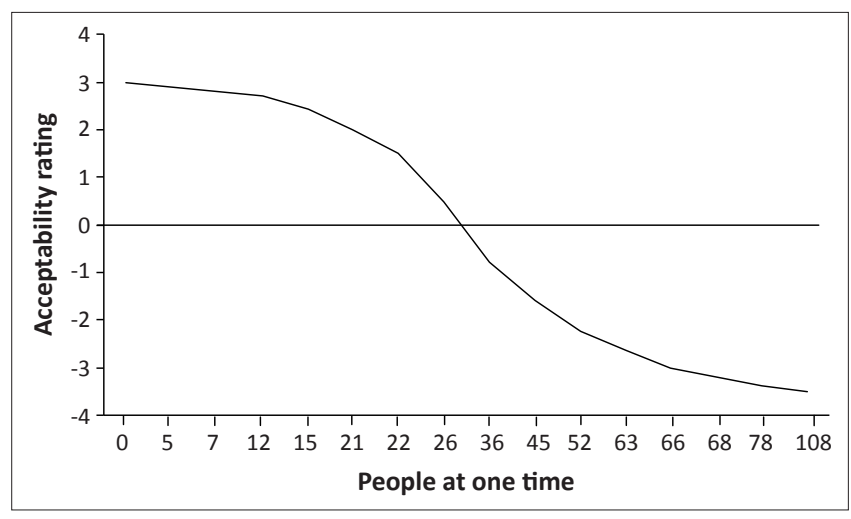

Source: Adapted from Manning, R., 2001, 'Visitor experience and resource protection: A framework for managing the carrying capacity of national parks', Journal of Park and Recreation Administration 19, 93-108

FIGURE 3: Average acceptability ratings for the 16 photographs illustrating a range of people at one time at Delicate Arch in Arches National Park, Utah.

features and areas in the Park (National Park Service 1995). The Park is now monitoring indicator variables to ensure that standards of quality are being maintained.

\section{Monitoring indicators of quality}

The management framework described above includes monitoring indicators of quality. However, monitoring some indicators, such as the number of groups encountered along a 
trail network, can be difficult to directly observe. Moreover, it would be useful to be able to estimate the maximum amount of visitor use that can be accommodated in a park without violating the standards of quality that have been set (a form of 'proactive monitoring') (Lawson et al. 2003). Computerbased simulation modelling can be used to address both of these issues.

Simulation modelling has become an important tool in many fields of study and practice and is increasingly being applied in management of parks and outdoor recreation (Cole 2005). An example of its usefulness as a monitoring tool is manifested in a study at Yosemite National Park, California (Manning et al. 2002). Much of the recreational use of the Park is focused on Yosemite Valley and its iconic attractions, including sheer granite walls of up to $1500 \mathrm{~m}$ and several waterfalls that are amongst the highest in the world. The Park accommodates over 4 million visits per year and its carrying capacity is a perennial and contentious issue.

Research at Yosemite was conducted in two phases. The first phase used a series of visitor surveys to support formulation of indicators and standards of quality for the visitor experience (much like the study at Arches described above). Many visitors reported that crowding was an important indicator of quality at attraction sites (i.e. the number of PAOT at an attraction site) and along trails (i.e. the number of people per viewscape along trails or persons-per-viewscape [PPV]). Visitors also reported standards of quality - maximum acceptable PAOT and PPV - for these indicator variables.

The second phase of research focused on developing simulations of visitor use at important attraction sites and trails. These simulation models were designed to estimate the maximum number of visitors that could be accommodated at these sites and trails without violating the PAOT and PPV standards of quality found in the first phase of research. Observations and counts of visitor use at several sites and trails were conducted, including number of visitors arriving per hour, visitor group size, length of time visitors stop at attraction sites, the speed at which visitors hike and the length of typical trail viewscapes (how far ahead hikers can typically see along trails). Simulation models of visitor use were developed using these and other data. Models were constructed using the commercially available, objectoriented simulation software, Extend. The object orientation of the software does not require code-writing and enables programming through graphic display of objects and connections.

The model was constructed to provide output in both graphic and numeric formats. Figure 4, for example, provides a graphic display of minute-by-minute PPV levels along the trail to Bridalveil Fall over the duration of a day. This output was derived from a model run using an average summer day total use level of 1415 visitors (derived from the counts of visitor use). The primary use of the study models was to estimate the maximum total daily use that could be accommodated at each study site without violating crowding-related standards of quality. Models were run multiple times to estimate these numbers.
The simulation models for Bridalveil Fall suggest that a maximum of 3200 visitors a day can be accommodated on the trail to Bridalveil Fall without violating the PPV standard of quality, but that only 1700 visitors a day can be accommodated at the base of Bridalveil Fall without violating the PAOT standard of quality.

\section{Implementing management actions to ensure standards of quality are maintained}

The management framework described above requires that management action be taken when monitoring demonstrates that standards of quality have been violated or are in danger of being violated. But how effective are alternative management actions? Research can help evaluate the potential efficacy of selected management practices.

A study of recreation at the summit of Cadillac Mountain in Acadia National Park, Maine is an example of the way in which research can help guide management (Park et al. 2008). Acadia attracts nearly 2.5 million visits per year and the Park is less than 20000 ha; this makes Acadia a very intensively used national park. Cadillac Mountain is an especially popular visitor attraction as its summit offer expansive views and is accessible by both road and trail. More than 5000 visitors per day may ascend the Mountain on peak summer days (Baldwin \& LaPage 2003; Turner \& LaPage 2001). A short, paved loop trail is provided for visitor use. Unfortunately, many visitors walk off the maintained trail and this has caused extensive damage to the summit's fragile soils and vegetation (Evan 2002; Turner \& LaPage 2001).

A research project was administered to test the efficacy of alternative management practices designed to encourage visitors to stay on the maintained trail. The study employed a series of experimental treatments - five management practices from 'indirect' (e.g. information and education) to 'direct' (e.g. a fence bordering the trail) and associated controls. During all treatment and control periods, researchers unobtrusively observed visitors and recorded the number that walked off the maintained trail. In addition, a survey of visitors was conducted to explore why the

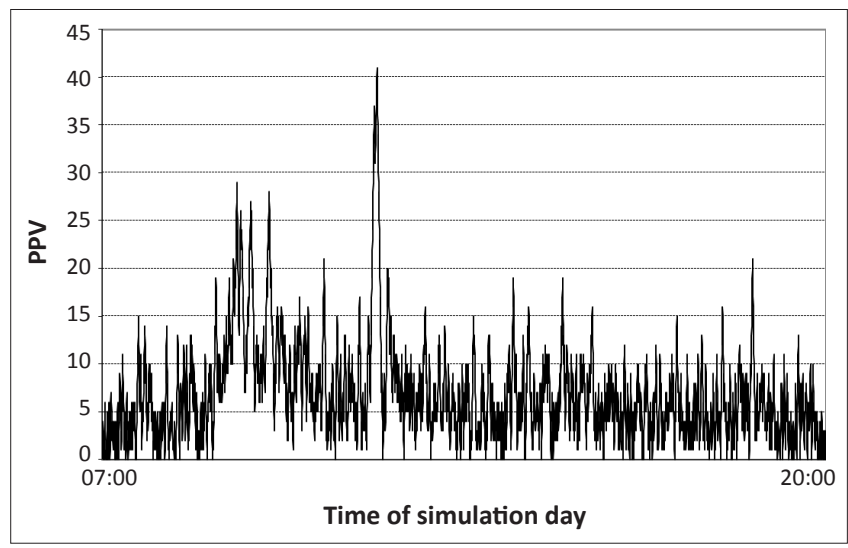

Source: Adapted from Manning, R., Valliere, W., Wang, B., Lawson, S. \& Newman, P., 2002, 'Estimating day use social carrying capacity in Yosemite National Park', Leisure 27(1-2), 77-102 'Estimating day use social carryin

FIGURE 4: Persons-per-viewscape along the trail to Bridalveil Fall in Yosemite National Park, California. 
experimental management treatments worked or not. Study findings suggest that all of the experimental management treatments reduced the percentage of visitors who walked off the maintained trail. More aggressive applications of indirect management practices were more effective than less aggressive applications and the direct practice of fencing was the most effective. However, none of the indirect management practices reduced off-trail walking enough to effectively limit damage to soils and vegetation.

Implications of the study are that a coordinated programme of indirect and direct management practices be implemented at Cadillac Mountain (and similar sites) that includes, (1) a rule requiring that visitors stay on maintained trails, (2) enforcement of this rule as necessary, (3) unobtrusive fencing along the margins of the trail, (4) redesigning of the maintained trail to extend it, widen it, and to provide spur trails to key photo points and (5) an aggressive education programme informing visitors of the regulation to stay on maintained trails and the reason for this regulation.

\section{A growing body of research and associated literature}

The studies outlined above are a part of a growing body of research and associated scientific and professional literature that can help guide management of parks and protected areas for outdoor recreation and tourism. These advances can help build the capacity of park and protected area management agencies in several ways. Firstly, research has supported development of a number of conceptual and management frameworks (Manning 2011b; McCool, Clark \& Stankey 2007). Conceptual frameworks - such as carrying capacity (Manning 2007; Shelby \& Heberlein 1986; Wagar 1964; Whittaker et al. 2011), common property resources (Hardin 1968), limits of acceptable change (Frissell \& Stankey 1972), the recreation opportunity spectrum (Brown, Driver \& McConnell 1978; Clark \& Stankey 1979; Driver \& Brown 1978), sustainable tourism and ecotourism (Buckley 2009; Honey 2008), ecosystem management (Agee \& Johnson 1987; Grumbine 1994), adaptive management (Holling 1978; Lee 1993; Stankey et al. 2005; Walters 1986) and social and environmental justice (Floyd 1999; Solop, Hagen \& Ostergren 2003; Stanfield McCown et al. 2012) - identify and analyse issues vital to management of parks and protected areas and offer managers organisational structures to think through these important issues. Moreover, these conceptual frameworks have formed the foundation for a number of management frameworks such as LAC and VERP, as discussed in this article. A number of related management frameworks have been developed and applied in parks and protected areas around the world, offering a choice of management frameworks from which to choose (Belokurov et al. 2009; Brown et al. 2006; Environment Canada and Park Service 1991; Graefe, Kuss \& Vaske 1990; Hockings 2003; Hockings, Carter \& Leverington 1998; Hockings et al. 2006; Jacobson et al. 2009; McCool et al. 2007; Moore, Smith \& Newsome 2003; Nilsen \& Tayler 1997; Pavese, Leverington \& Hockings 2007; Shelby \& Heberlein 1986). The similarity of many of these frameworks suggests that it may be more important to choose and apply any one of the frameworks than to struggle with the choice of which framework is 'best' (Manning 2004).

Secondly, there is a growing body of research on indicators and standards of quality for managing outdoor recreation and tourism in parks and protected areas. These studies address both park resources (Hammitt \& Cole 1998) and the quality of the visitor experience (Manning 2011a) and use a diverse set of natural and social science research methods. Indicators and standards of quality have begun to be compiled in several synthetic sources (Manning 2011a; National Park Service 2013).

Thirdly, monitoring protocols have been developed and applied in diverse settings and these can guide development and application of monitoring of visitor use of parks and protected areas, as well as the ecological and experiential impacts of this use (Newsome, Moore \& Dowling 2013). For example, handbooks for monitoring visitor use and associated encounters amongst visitors in wilderness areas have been developed (Watson, Cronn \& Christensen 1998; Watson et al. 2000). Similarly, guidelines for monitoring visitor impacts on trails, campsites and related areas have been developed (Leung \& Monz 2006; Marion \& Leung 2011; Monz \& D'Luhosch 2010). Monitoring incorporates a range of techniques, including automated counters, visitor surveys, remote sensing, global positioning systems and simulation modelling (Cole 2005; Gimblett \& Skov-Peterson 2008; Kim \& Daigle 2011; Lawson 2006; Newsome et al. 2013).

Fourthly, a substantial body of research is addressing the effectiveness of alternative management practices applied to parks and protected areas (Buckley 2004; Manning 2011a). This body of work has identified a range of management strategies and practices, tested the effectiveness of these practices in diverse contexts and has begun to develop a series of principles to guide the application of management practices (e.g. Manning 2003, 2011a). Moreover, a recent book has developed a matrix-based approach to considering alternative strategies and practices, along with a series of 20 case studies of effective management of outdoor recreation and tourism in national parks (Manning \& Anderson 2012).

Fifthly, the research illustrated above has been conducted in a number of parks and protected areas around the world and this has contributed to the growing body of scientific and professional literature on management of parks and protected areas in diverse environmental, social and managerial contexts. Emergence of a number of books that integrate and synthesise this body of work is an encouraging sign of the growing maturity of the field of park and protected area management for outdoor recreation and tourism (Buckley 2004, 2009; Eagles \& McCool 2002; Hammitt \& Cole 1998; Hsu et al. 2010; Manning 2007, 2011a; McCool \& Moisey 2008; Newsome et al. 2013). This growing body of scientific and professional work is helping build the capacity of park and protected area management. Close collaboration between 
managers and scientists will aid in successful management of parks and protected areas for outdoor recreation and tourism (Manning 2011a; McCool et al. 2007).

\section{Ethical considerations}

Some of the data reported in this article were collected as part of surveys of visitors to several units of the US national park system. These surveys were approved by institutional review committees of the principal investigator's university. These surveys were administered on a voluntary basis and potential respondents were told the purpose of the surveys and approximately how long they would take. Response rates were very high as most visitors to the national parks are inherently interested in how these areas are managed and are pleased to report on their experiences and attitudes toward park management issues. Respondents' names are not recorded to assure anonymity and confidentiality.

\section{Trustworthiness}

The reliability and validity of the data reported in this article are supported by publication of findings from these and related studies in many papers published in the peerreviewed scientific literature. All of these papers have been reviewed by a minimum of three external reviewers who have examined all facets of these studies, including reliability and validity.

\section{Conclusion}

Parks and protected areas have seen substantial growth in recent decades. However, management of these areas requires careful attention to maximise their potential environmental and societal values and to minimise potential conflict between public use of parks and protected areas and protection of park resources and the quality of the visitor experience. A recent study suggests that there is considerable room for improvement in management effectiveness (Leverington et al. 2010). Based on compilation and analysis of over 8000 assessments of park and protected area management across the world, the authors conclude that $42 \%$ of cases were judged to have major deficiencies. However, application of research was found to be positively correlated with management effectiveness. This suggests that management should be based on the growing body of scientific and professional literature.

Outdoor recreation and tourism are increasingly important uses of parks and protected areas. However, they can also challenge park managers to minimise the potential impacts of tourism and outdoor recreation on park resources and the quality of the visitor experience. Management-by-objectives frameworks have emerged from the scientific and professional literature that can guide planning and management of parks and protected areas for outdoor recreation and tourism. These management frameworks draw on the broader literature in environmental planning and management and can be supported by a programme of research. The examples of this type of research outlined in this article suggest ways in which research can help inform each of the three primary steps of the management-by-objectives framework, (1) formulating indicators and standards of quality, (2) monitoring indicators of quality and (3) implementing management actions to help ensure that standards of quality are maintained. These and related programmes of research around the world can help inform management of parks and protected areas for outdoor recreation and tourism.

\section{Acknowledgements Competing interests}

The author declares that he has no financial or personal relationships that may have inappropriately influenced him in writing this article.

\section{References}

Agee, J. \& Johnson, D., 1987, Ecosystem management for parks and wilderness, University of Washington Press, Seattle.

Baldwin, E. \& LaPage, W., 2003, Visitor behaviors and resource impacts at Cadillac Mountain Acadia National Park, Part II: Sign comparison study summer 2002 Technical report for Acadia National Park Natural Resources Division.

Balmford, A., Beresford, J., Green, J., Naidoo, R., Walpole, M. \& Manica, A., 2009, 'A global perspective on trends in nature-based tourism', PLoS Biol 7(6), e1000144. http://dx.doi.org/10.1371/journal.pbio.1000144

Belokurov, A., Besancon, C., Pavese, H., Burgess, N.D., Dudley, N., Stolton, S. et al., 2009, 'New resources for assessing the effectiveness of management in protected areas', Oryx 43(1), 14.

Brown, P., Driver, B. \& McConnell, C., 1978, 'The opportunity spectrum concept in outdoor recreation supply inventories: Background and application', Proceedings of the integrated renewable resource inventories workshop, USDA Forest Service general technical report RM-55, pp. 73-84.

Brown, G., Koth, B., Kreag, G. \& Weber, D., 2006, Managing Australia's protected areas: A review of visitor anagement models, frameworks, and processes, Sustainable Tourism Cooperative Research Center, Gold Coast.

Buckley, R. (ed.), 2004, Environmental impacts of ecotourism, CABI Publishing, Wallingford. http://dx.doi.org/10.1079/9780851998107.0000

Buckley, R., 2009, Ecotourism principles and practices, Cambridge University Press, Cambridge.

Christensen, N., Bartuska, A., Brown, J., Carpenter, S., D’Antonio, C., Francis, R. et al., 1996, 'Report of the Ecological Society of America committee on the scientific basis for ecosystem management', Ecological Applications 6, 665-691. http:// dx.doi.org/10.2307/2269460

Clark, R. \& Stankey, G., 1979, The recreation opportunity spectrum: A framework for planning, management, and research, USDA Forest Service Research Paper PNW98.

Cole, D.N. (compiler), 2005, Computer simulation modeling of recreation use: Current status, case studies, and future directions, General technical report RMRS GTR-143, US Department of Agriculture Forest Service, Rocky Mountain Research Station, Fort Collins.

Davenport, L., Brockelman, W.Y., Wright, P.C., Ruf, K. \& Rubio del Valle, F.B., 2002, 'Ecotourism tools for parks', in J. Terborgh, C. van Schaik, L. Davenport \& M. Rao (eds.), Making parks work, pp. 279-306, Island Press, Washington, DC

Driver, B. \& Brown, P., 1978, 'The opportunity spectrum concept in outdoor recreation supply inventories: A rationale', Proceedings of the integrated renewable resource inventories workshop, USDA Forest Service general technical report RM-55, pp. 73-84.

Eagles, P.F.J. \& McCool, S.F., 2002, Tourism in national parks and protected areas: Planning and management, CABI Publishing, Wallingford. http://dx.doi. org/10.1079/9780851995892.0000

Environment Canada and Park Service, 1991, Selected readings on the visitor activity management process, Environment Canada, Ottawa.

Evans, C.B., 2002, Summit steward 2002 season report, Acadia National Park, Maine.

Floyd, M., 1999, 'Race, ethnicity and use of the national park system', Social Science Research Review 1(2), 1-23.

Frissell, S. \& Stankey, G., 1972, 'Wilderness environmental quality: Search for social and ecological harmony', Proceedings of the Society of American Foresters Annual Conference, Hot Springs, 01-05 October 1972, pp. 170-183.

Gimblett, R. \& Skov-Peterson, H. (eds.), 2008, Monitoring, simulation, and management of visitor landscapes, University of Arizona Press, Tucson.

Goodwin, H.J., 1996, 'In pursuit of ecotourism', Biodiversity Conservation 5, 277-291. http://dx.doi.org/10.1007/BF00051774 
Graefe, A., Vaske, J. \& Kuss, F., 1984, 'Social carrying capacity: An integration and synthesis of twenty years of research', Leisure Sciences $8,275-295$. http://dx.doi. synthesis of twenty years of research
org $10.1080 / 01490408609513076$

Graefe, A.R., Kuss, F.R. \& Vaske, J.J., 1990, Visitor impact management: The planning framework, vol. 2, National Parks and Conservation Association, Washington, DC.

Grumbine, R., 1994, 'What is ecosystem management?', Conservation Biology 8, 2738. http://dx.doi.org/10.1046/j.1523-1739.1994.08010027.x

Hammitt, W.E. \& Cole, D.N., 1998, Wildland recreation: Ecology and management, Wiley, New York.

Hardin, G., 1968, 'The tragedy of the commons', Science 162, 1243-1248. http:// dx.doi.org/10.1126/science.162.3859.1243, PMid:17756331

Hockings, M., Carter, B. \& Leverington, F., 1998, 'An integrated model of public contact planning for conservation management', Environmental Management 22(5), 643654. http://dx.doi.org/10.1007/s002679900136, PMid:9680534

Hockings, M., 2003, 'Systems for assessing the effectiveness of management in protected areas', BioScience 53(9), 823-832. http://dx.doi.org/10.1641/00063568(2003)053[0823:SFATEO]2.0.CO;2

Hockings, M., Stolton, S., Dudley, N., Leverington, F. \& Courrau, J., 2006, Evaluating effectiveness: A framework for assessing the management of protected areas, 2 nd edn., IUCN, Gland. http://dx.doi.org/10.2305/IUCN.CH.2006.PAG.14.en

Holling, C., 1978, Adaptive environmental assessment and management, John Wiley \& Sons, London.

Honey, M., 2008, Ecotourism and sustainable development, 2nd edn., Island Press, Washington, DC.

Hsu, Y-C., Leung, Y-F. Li, Y-H., Wang, C-P. \& Lue, C-C., 2010, An assessment of frameworks useful for public land recreation planning, Hua Li Publishing, Taipei.

International Union for Conservation of Nature \& United Nations Environment Programme World Conservation Monitoring Centre, 2011, The world database on protected areas (WDPA): January 2011, UNEP-WCMC, Cambridge.

International Union for Conservation of Nature \& United Nations Environment Programme World Conservation Monitoring Centre, 2012, The world database on protected areas (WDPA): February 2012, UNEP-WCMC, Cambridge.

Jacobson, C., Hughey, K.F.D., Allen, W.J., Rixecker, S. \& Carter, R.W., 2009, 'Toward more reflexive use of adaptive management', Society \& Natural
Resources: An International Journal 22(5), 484-495. http://dx.doi. org/10.1080/08941920902762321

Kim, M-K. \& Daigle, J.J., 2011, 'Detecting vegetation cover change on the summit of Cadillac Mountain using multi-temporal remote sensing datasets: 1979, 2001, and 2007', Environmental Monitoring and Assessment 180, 63-75. http://dx.doi. and 2007', Environmental Monitoring and Assessmen
org/10.1007/s10661-010-1772-1, PMid:21082342

Lawson, S., Manning, R., Valliere, W. \& Wang, B., 2003, 'Proactive monitoring and adaptive management of social carrying capacity in Arches National Park: An application of computer simulation modeling', Journal of Environmental
Management 68, 305-313. http://dx.doi.org/10.1016/S0301-4797(03)00094-X

Lawson, S.R., 2006, 'Computer simulation as a tool for planning and management of visitor use in protected natural areas', Journal of Sustainable Tourism 14(6), 600-617. http://dx.doi.org/10.2167/jost625.0

Lee, K., 1993, Compass and gyroscope: Integrating science and politics for the environment, Island Press, Washington, DC.

Leung, Y-F. \& Monz, C.A., 2006, 'Visitor impact monitoring: What, why, and how?', George Wright Forum 23(2), 7-10.

Leverington, F., Costa, K.L., Pavese, H., Lisle, A. \& Hockings, M., 2010, 'A global analysis of protected area management effectiveness', Environmental Management 46,

Manning, R., 2001, 'Visitor experience and resource protection: A framework for managing the carrying capacity of national parks', Journal of Park and Recreation Administration 19, 93-108.

Manning, R., 2003, 'Emerging principles for using information/education in wilderness management', International Journal of Wilderness 9(1), 20-27.

Manning, R., 2004, 'Recreation planning frameworks', in J.J. Vaske (ed.), Society and natural resources: A summary of knowledge, pp. 83-96, Modern Litho, Jefferson.

Manning, R., 2007, Parks and carrying capacity: Commons without tragedy, Island Press, Washington, DC.

Manning, R., 2009, Parks and people: Managing outdoor recreation at Acadia National Park, University of Vermont Press, Burlington.

Manning, R., 2011a, Studies in outdoor recreation, Oregon State University Press, Corvallis.

Manning, R., 2011b, 'Frameworks for defining and managing the wilderness experience', in D.N. Cole (compiler), Wilderness visitor experiences: Progress in research and management, pp. 158-176, Proceedings RMRS-P-66, US Department of Agriculture Forest Service Rocky Mountain Research Station, Fort Collins.

Manning, R. \& Anderson, L., 2012, Managing outdoor recreation: Case studies in the national parks, CABI Publishing, Wallingford. http://dx.doi. org/10.1079/9781845939311.0000

Manning, R. \& Freimund, W., 2004, 'Use of visual research methods to measure standards of quality for parks and outdoor recreation', Journal of Leisure Research 36(4), 557-579.

Manning, R., Freimund, W., Lime, D. \& Pitt, D., 1996, 'Crowding norms at frontcountry sites: A visual approach to setting standards of quality', Leisure Sciences 18, 39sites: A visual approach to setting standards of quality',
59. http://dx.doi.org/10.1080/01490409609513271

Manning, R., Valliere, W., Wang, B., Lawson, S. \& Newman, P., 2002, 'Estimating day use social carrying capacity in Yosemite National Park', Leisure 27(1-2), 77-102.
Marion, J. \& Leung, Y-F., 2011, 'Indicators and protocols for monitoring impacts of formal and informal trails in protected areas', Journal of Tourism \& Leisure Studies $17(2), 215-236$.

Mastny, L., 2001, Treading lightly: New paths for international tourism, Worldwatch Institute, Washington, DC.

McCool, S., 1994, 'Planning for sustainable nature dependent tourism development: The limits of acceptable change system', Tourism Recreation Research 19, 51-55.

McCool, S. \& Cole, D. (eds.), 1997, Proceedings - Limits of acceptable change and related planning processes: Progress and future direction, Missoula, Montana, 20-22 May 1997, General technical report INT-371, US Department of Agriculture Forest Service Intermountain Research Station, Ogden.

McCool, S.F., Clark, R.N. \& Stankey, G.H., 2007, An assessment of frameworks useful for public land recreation planning, General technical report PNW-GTR-705, US Department of Agriculture Forest Service, Pacific Northwest Research Station, Portland.

McCool, S. \& Moisey, R.N., 2008, Tourism, recreation and sustainability: Linking culture and environment, 2nd edn., CABI, Cambridge. http://dx.do. org $/ 10.1079 / 9781845934705.0000$

Moore, S.A., Smith, A.J. \& Newsome, D.N., 2003, 'Environmental performance reporting for natural area tourism: Contributions by visitor impact management frameworks and their indicators', Journal of Sustainable Tourism 11(4), 348-375. http://dx.doi.org/10.1080/09669580308667211

Monz, C. \& D'Luhosch, P., 2010, 'A simplified image analysis method for monitoring wilderness campsites', International Journal of Wilderness 16(1), 26-31.

National Park Service, 1995, Visitor experience and resource protection implementation plan: Arches National Park, Denver Service Center, Denver.

National Park Service, 1997, VERP: The visitor experience and resource protection (VERP) framework - A handbook for planners and managers, Denver Service Center, Denver.

National Park Service, 2013, National Park Service park planning, viewed 17 September 2013, from http://parkplanning.nps.gov/planningHome.cfm

Newsome, D., Moore, S.A. \& Dowling, R.K., 2013, Natural area tourism: Ecology, impacts, and management, 2nd edn., Channel View Publications, Bristol.

Nilsen, P. \& Tayler, G., 1997, 'A comparative analysis of protected area planning and management frameworks', in S.F. McCool \& D.N. Cole (eds.), Proceedings Limits of acceptable change and related planning processes: Progress and future direction, Missoula, Montana, 20-22 May 1997, General technical report INT-371, US Department of Agriculture Forest Service Intermountain Research Station, Ogden, pp. 49-57.

Park, L., Manning, R., Marion, J., Lawson, S. \& Jacobi, C., 2008, 'Managing visitor impacts in parks: A multi-method study of the effectiveness of alternative management practices', Journal of Park and Recreation Administration 26(1) 97-121.

Pavese, H.B., Leverington, F. \& Hockings, M., 2007, 'Global study of protected areas management effectiveness: The Brazilian perspective', Natureza \& Conservacao 5(1), 152-162.

Shelby, B. \& Heberlein, T., 1986, Carrying capacity in recreation settings, Oregon State University Press, Corvallis.

Society of American Foresters, 1993, Sustaining long-term forest health and productivity, Society of American Foresters, Bethesda.

Solop, F., Hagen, K. \& Ostergren, D., 2003, Ethnic and racial diversity of national park system visitors and non-visitors, National Park Service technical report, viewed 16 August 2010, from http://www.nature.nps.gov/socialscience/docs/archive/ EthnicAndRacialDiversity.pdf

Stanfield McCown, R., Laven, D., Manning, R. \& Mitchell, N., 2012, 'Engaging new and diverse audiences in the national parks: An exploratory study of current knowledge and learning needs', The George Wright Forum 29(2), 129-138.

Stankey, G., Clark, R. \& Bormann, B., 2005, Adaptive management of natural resources: Theory, concepts and management institutions, USDA Forest Service general technical report PNW-GTR-654.

Stankey, G., Cole, D., Lucas, R., Peterson, M., Frissell, S. \& Washburne, R., 1985, The limits of acceptable change (LAC) system for wilderness planning, USDA Forest Service general technical report INT-176.

Stankey, G. \& Manning, R., 1986, 'Carrying capacity of recreation settings', A literature review: The President's commission on Americans outdoors, pp. M-47-M-57, US Government Printing Office, Washington, DC.

Turner, R. \& LaPage, W., 2001, Visitor behaviors and resource impacts at Cadillac Mountain, Acadia National Park, Cooperative agreement 1443CA4520-A-0015, US Department of the Interior, Washington, DC.

Wagar, J.A., 1964, 'The carrying capacity of wild lands for recreation', Forest Science Monograph 7, n.p.

Walters, C., 1986, Adaptive management of renewable natural resources, Macmillan, New York.

Watson, A.E., Cronn, R. \& Christensen, N.A., 1998, Monitoring inter-group encounters in wilderness, Research paper RMRS-RP-14, US Department of Agriculture Forest Service, Rocky Mountain Research Station, Fort Collins.

Watson, A.E., Cole, D.N., Turner, D.L. \& Reynolds, P.S., 2000, Wilderness recreation use estimation: A handbook of methods and systems, General technical report RMRSGTR-56, US Depart
Station, Ogden.

Whittaker, D., Shelby, B., Manning, R., Cole, D. \& Haas, G., 2011, 'Capacity reconsidered: Finding consensus and clarifying differences', Journal of Park and reconsidered: Finding consensus and
Recreation Administration 29(1), 1-20.

World Travel and Tourism Council, 2007, The global travel and tourism summit, World Travel and Tourism Council, London. 